\title{
Banjar Language Shifting in Ecolinguistics Perspective
}

\author{
Imam Hendra Saputra*, Ninuk Krismanti, Agustina Lestary \\ Program Studi Pendidikan Bahasa Inggris, STKIP PGRI Banjarmasin, Indonesia \\ *imam.hendra.s@stkipbjm.ac.id,ninukkrismanti@stkipbjm.ac.id, \\ agustinalestary@stkipbjm.ac.id
}

DOI: 10.20884/1.jli.2021.12.2.4770

\begin{abstract}
Article History:
First Received:

ABSTRACT

$31 / 08 / 2021$

The research attempts to examine language shifts that occur in the Banjar

Final Revision: community using an ecolinguistics approach. The language shifts studied were

$18 / 12 / 2021$ limited to the vocabulary shift commonly used in the social interactions of everyday Banjar people. The data gathering was using interviewing and documentation techniques. Interviews are semi-structured interviews. The Available online: interview was on respondents spread across various cities in South Kalimantan, where the Banjar language is the language of community $31 / 12 / 2021$ communication. Due to the pandemic, researchers enlisted the help of students in their respective hometowns to collect data with protocols that the research team had established. The data was the subject of reduction, organized by category of word classes and reasons for shifts, analysed based on the threedimensional social theory of language praxis. The three practical social dimensions of language are the ideological, social, and biological dimensions. The research expects to be a reference for Banjar language participation efforts.
\end{abstract}

Keywords: Banjar language; ecolinguistics; language shift

\section{INTRODUCTION}

Language is organic. It means that language lives, evolves and can die. Many theories have been put forward about the origin of language. One of them is that language arises because humans study the surrounding nature, especially the sounds produced. It is not only from a few vocabularies because of sounds coming from certain animals or objects in nature. The naming of a 'gecko' animal, for example, comes from the sound coming out of the animal.

In addition to being bound to nature, language is also bound to the socio-economic conditions of its users. The words, metaphors, and proverbs often describe the beliefs and conditions of the origin of the language. The language used in areas where users live adjacent 
to the water and the majority of people's livelihoods are fishermen will have a variety of vocabulary related to water and special terms used by fishermen.

Just like other living organisms, language can also develop. Language development can occur for various reasons, such as changes in the natural conditions from which the language originated, economic and social conditions changes, and ideological shifts and user beliefs. As these changes occur, language shifts occur.

The goal of the research was to investigate the shift that occurred in the Banjar language. Banjar is an Austronesian language of the Melayik language family spoken by the Banjar tribe in South Kalimantan, Indonesia, as the mother tongue. Banjar language is on the list of dominant languages in Indonesia. Some linguists argue that Banjar belongs to the East Borneo Malay group. The East Borneo group also lowered two groups, namely North Borneo and Southeast Borneo. Southeast Borneo lowered one branch, which eventually lowered the Berau and Kutai languages; the South Borneo group lowered the Banjar and Bukit languages.

Zainuddin (2008) reported that according to Mukhlis Maman, an observer of the Banjar language revealed that the Malay language strongly influences nearly $99 \%$ of South Kalimantan (Kalsel) people who speak the Banjar language. Nevertheless, Dayak is also part of the influences. Affected by the two languages, from the perspective of phonology and morphology, Banjar language consists of two languages, Banjar Hulu and Banjar Kuala.

The morphology of the upstream Banjar language uses much archaic vocabulary often used by the indigenous people of the hill ethnicity, while Banjar Kuala uses many ethnic Malay words. Another feature of upstream Banjar language users is the people who inhabit the temperate plains and hills and the crossing area, with dialectical relatively rigid, short, hard and fast. At the same time, the Banjar Kuala language is a community that inhabits the banks of rivers, seas, regional estuaries and stirring dialectically, shimmying, not hard and not fast. Therefore, the difference is not too noticeable; it is only possible in a few vocabularies, so there is no difficulty communicating or conversing between the two language character regions.

Like other regions, South Kalimantan, where the Banjar language is common, is also experiencing geographical, social and economic changes. South Kalimantan has a highland area formed by the Meratus mountains and a lowland area formed by swamps and rivers. However, some South Kalimantan areas have switched functions into residential, industrial, and plantation areas. Changes in the functioning of It region also impact changes in the social and economic conditions of its people. The livelihoods of the people of Banjar today are not only in agriculture and trade but also penetrate the industry and other formal sectors. 
In the end, the changes that occurred in South Kalimantan also triggered several changes in the Banjar language. Some words - especially those related to plants and animals - are rarely used by the Banjar community. Vocabulary closely related to work that intersects with nature has begun to be replaced with new vocabulary along with jobs that are no longer just farming or trading but also employees in various sectors. The study expects to document the rarely used Banjar vocabulary and help participate in the enrichment of the regional language.

\section{MATERIALS AND METHOD}

The purpose of This study is to describe the phenomenon of shifting the Banjar language as it is. Therefore, the most suitable method for This research is qualitative descriptive methods. According to Mukhtar (2013), qualitative descriptive research is a type of research whose purpose is to describe the phenomena that occur in research objects when research takes place without intervention from researchers. In the study, data retrieval was done in a natural setting that researchers did not give special treatment to study respondents.

This research data is a list of vocabulary previously used by the Banjar community that is no longer used or replaced with other words. The research was in several cities and districts in South Kalimantan, where the Banjar language is common in everyday life. For pandemic reasons, researchers did not jump directly into the field but asked for the help of students in their respective hometowns to help the data retrieval process according to their current domicile. In the ecolinguistics sphere, the relationship of language and environment exists at the lexicon level only, not at the phonological or morphological level (Sitanggang et al., 2018). So, the regional language used can show the state of nature by using a lexicon related to livelihoods or natural resources in the area. Therefore, the focus of data retrieval in the study is on the lexicon level, not other more complex levels.

Data gathering is by interviews with Banjar language users. The interviews in the study are semi-structured interviews conducted with respondents in the cities and districts. Interviews are selected as data collection techniques so that the collected data is authentic.

The data collecting method is by interviewing the respondents to name a word that was previously used frequently but is now rarely or never used again. The interviews are also to get information about the causes of Banjar language shifts in the user community. In addition to interviews, data is also obtained through documentation techniques. Banjar vocabulary is collected from digital sources and physical documents to be examined whether there is a shift in language or not. 
Interview results and documentation analysis are reduced so that data unrelated to the purpose of the study can be ignored. Then, the data in the form of a reduced lexicon is arranged based on the class he said and based on the reason why the vocabulary shifted. The data analysis technique applied is an inferential technique whose role of researchers as members of the Banjar community becomes important in deciding whether the vocabulary that has been collected has shifted or survived. Next, the vocabulary that has been analysed is presented in the form of a description. Conclusions are drawn based on the results of the analysis and description conducted earlier.

\section{RESULTS \& DISCUSSION}

Because language is equated with other living things, it is reasonable if language is developed. Development here can be interpreted as change, which means that there will be a part of one language, usually a lexicon, that is abandoned because it is replaced by another lexicon or because it is no longer relevant to its use in the current situation. Changes that occur in language occur because, in fact, the language itself cannot be separated from all human activities and movements as cultural and social creatures. The relationship between language and humans makes language dynamic.

Language changes can be changes to the rules in the language - whether existing rules should be changed, whether they disappear, new rules and so on. These changes can actually occur in all parts of the language, whether at the phonological, morphological, syntactic, semantic, or other levels (Lindø \& Bundsgaard, 2000). However, as explained earlier, the initial changes usually occur at the lexicon level before touching another level. Changes that occur in any language do not happen instantly. Usually, changes can be felt after a long period of time due to changes in human interaction, natural disasters, or natural changes. Changes in language are an unavoidable cultural phenomenon.

Language is one element of culture, as one of the elements of culture, growth, and development of language is influenced by the prevailing culture in the area where the language is produced or used. Culture in certain areas is generally influenced by the livelihood system carried out by residents in the local area so that the language used is coloured by vocabulary related to the livelihood system of the area. It means that language life is not separated from the environment in which it lives, so there is no doubt that language and environment have a close relationship. The two have a reciprocal relationship, i.e., language reflects the environment and the environment reflects language. 
The environment is understood as a language-user society, as one of the language codes (Fill \& Mühlhäusler, 2001). Language resides only in the minds of its speakers, and therefore language only works when it is used to connect speakers and connect speakers with the environment, both social and natural environment, using and conveying the language to others.

So, the regional language used can show the state of nature by using a lexicon related to terms, livelihoods or natural resources in the area. For example, in one of the areas that became the location of data retrieval, namely in Pengaron, Banjar Regency, vocabulary that is widely used in people's daily lives is still related to the environmental conditions of the area. Examples of terms used by the People of Pengaron to indicate the natural conditions in their area are:

Table 1 Examples of terms in Banjar

\begin{tabular}{|c|c|c|c|}
\hline No & Term & Meaning & Information \\
\hline 1. & Pagaran & ain & $\begin{array}{l}\text { The word "fence" indicates the natural condition of the } \\
\text { village because the purpose of the word "fence" is a } \\
\text { mountain that surrounds the village, as well as the fence that } \\
\text { surrounds the house. }\end{array}$ \\
\hline 2. & Parta & Blue Lake & $\begin{array}{l}\text { The word "parta" also denotes the natural conditions of } \\
\text { Pengaron village, which means "parta" is a blue lake above } \\
\text { the mountains formed due to coal mines. }\end{array}$ \\
\hline 3. & $\begin{array}{l}\text { Oranje } \\
\text { Nassau }\end{array}$ & $\begin{array}{l}\text { Fort of } \\
\text { Defense }\end{array}$ & $\begin{array}{l}\text { The word "Oranje Nassau" also indicates the natural } \\
\text { condition of Pengaron village, because the village is located } \\
\text { in the mountains, so in the colonial era it was used as a } \\
\text { "fortress" of Dutch defense. }\end{array}$ \\
\hline
\end{tabular}

Metaphors used in the village of Pengaron that show natural conditions are:

Table 2 Examples of metaphors in Banjar

\begin{tabular}{lll}
\hline No. & Metaphor/language & Information \\
\hline 1 & Kaya pinang di balah dua & It means equally fair, a similarity. \\
2 & Kaya warik tajun ka kacang & No shame, like a villager who sees the city (tacky) \\
3 & $\begin{array}{l}\text { Pahatian kaya buah } \\
\text { tampurikat }\end{array}$ & It means another in front of the other behind/ the \\
4 & $\begin{array}{l}\text { Kaya hayam kahilangan } \\
\text { umanya }\end{array}$ & It means confused/don't know to do anything. \\
5 & Tehadangi buah bungur & Something impossible \\
\hline
\end{tabular}


Conditions in the Pengaron area are mountains, so that the lexicon used to show the natural conditions that exist there can be the name of plants and vegetables planted by the community, namely:

Table 3 Examples of plant-related lexicons in Banjar Language

\begin{tabular}{lll}
\hline No. & Plant & Meaning \\
\hline 1 & Janar & Turmeric \\
2 & Kancur & Kencur \\
3 & Tipakan & Ginger \\
4 & Laus & Laos \\
5 & Sasawi & Mustard \\
6 & Gumbili & Cassava \\
7 & Bilungka & Cucumber \\
8 & Hanau & Aren Tree \\
9 & Banih & Rice \\
10 & Kustila & Papaya \\
11 & Waluh & Pumpkin \\
12 & Jaring & Jengkol \\
13 & Sahang & Pepper \\
14 & Kaladi & Taro \\
15 & Gatah & Rubber Tree \\
16 & Kasturi & Small black mango \\
17 & Tiwadak & Cempedak \\
\hline
\end{tabular}

Lexicons used to show the natural conditions in the village of Pengaron can also be in the form of animal names, namely:

Table 4 Examples of lexicons related to animals in Banjar Language

\begin{tabular}{lll}
\hline No. & Name of animal & Meaning \\
\hline 1 & Binjagan & Deer \\
2 & Hadangan & Buffalo \\
3 & Kuyuk & Dog \\
4 & Itik & Duck \\
5 & Hayam Kampung & Chicken \\
6 & Warik & Monkey \\
7 & Kukulai & Owl \\
8 & Kalulut & Honey fly \\
9 & Tabuan & Bee \\
10 & Sadu & Skunk \\
\hline
\end{tabular}

Examples of the findings above can be evidence that strengthens the Ecolinguistics theory of the interrelationship of language and the environment in which it lives. Although both use the Banjar language, differences in the environment where people live in Banjar will show some 
lexicon differences that are influenced by the physical and social conditions in which the speaker resides. The vocabulary found in Pengaron may be slightly different from the vocabulary understood by people living in Sarang Tiung, Kotabaru, due to differences in the environment in which speakers live.

The language a person uses is generally influenced by each person's socio-economic circumstances. People from good economic circles will get used to using Indonesian, they are also very concerned about the development of the language, while in people whose socio-economic conditions are low, they do not pay much attention to language development, and in general, they use regional languages when communicating.

Nevertheless, when someone has started to get along a lot with the environment they play in, their language will experience a shift that language in that person will affect each other (Lubis, 2014). A person who used to use Indonesian will be affected by the regional language that he gets from his peers. Likewise, with someone who used to use the regional language, his language will also be influenced by Indonesian, which he usually hears from his peers.

Banjar language can indicate a person's position in the family because each family member who is a sibling of the mother/father has a different nickname in Banjar language, as described in the table below:

Table 5 A various name for the siblings of the parent in Banjar language

\begin{tabular}{ll}
\hline Summons & Meaning \\
\hline Gulu & The oldest child \\
Angah & Child number 2 \\
Julak & Child number 3 \\
Amak/acil & Child number 4 \\
Busu/acil & Child number 5 \\
Ading & The last child \\
\hline
\end{tabular}

Lexicon related to livelihoods in the Banjar community is also closely related to the area where Banjar speakers live or come from. For example, for rubber plantation areas such as Halong, Pengaron and other areas where many people are gardening as well as raising, then the following lexicon will sound familiar: 
Table 6 Examples of lexicon commonly found in the Banjar community

\begin{tabular}{ll}
\hline Livelihood Lexicon & Meaning \\
\hline Manual & Dig for coal manually \\
Manyadap & Making Palm Sugar \\
$\underline{\text { Manurih }}$ & Cutting Rubber \\
$\underline{\text { Bahuma }}$ & Planting \\
\hline
\end{tabular}

The lexicon above will sound not so familiar to the people of Banjar who live in urban areas who do not have a knowledge attachment to livelihoods in plantation and livestock areas.

In an effort to answer the study question, the research team categorized lexicon in Banjar language that is rarely found or has shifted based on the class he said. The first category is nouns. Based on our findings, there are 43 nouns in the Banjar language that have undergone a shift as can be seen in the table below:

Table 7 The shift of nouns in Banjar language

\begin{tabular}{ll}
\hline Noun Vocabulary & Meaning \\
\hline Rambai & Fruit like langsat \\
Tampurikat & Fruit like mangosteen but its color is yellow \\
Pampakin & Fruit is like durian but it's orange \\
Karayi & Metimun \\
Kalakai & Fern leaves \\
Kalumpe & Cassava shoots \\
Maritam & The fruit is like hairless rambutan \\
Kulidang & Red flaky \\
Sangkuang & Her fruit is small like marbles its sour and sweet taste \\
Lahung & Fruit is like durian but its color is red \\
Adupan & Dog \\
Anguy & Chameleon \\
Lalak & Frog \\
Katikih & Large red ants \\
Agas & Small mosquitoes \\
Undur-undur & Group of insects \\
Anai-anai & White insects \\
Kijang & Deer \\
Tatangkut & Bee \\
Kakasiur & Dragonfly \\
Rumbih & Avalanche \\
Ba'ah & Sudden flooding \\
Arang & Land left \\
Indung & Mother \\
Rengge & Fish net \\
Ulatih & Corned \\
Mamarina & Aunt \\
Lalongkang & Window \\
\hline
\end{tabular}




\begin{tabular}{ll}
\hline Noun Vocabulary & Meaning \\
\hline Tangkuluk & Headgear \\
Motor & Car \\
Halu dan lasung & Tools to smooth coffee beans \\
Bakuan & Collected rubber \\
Bubungan & "atap" \\
Suluh & Torch \\
Biuku & Turtle \\
Sanayan & Monday \\
Sasudu & Spoon \\
Almanak & Calendar \\
Kartak & Road \\
Hambin & Terrace \\
Balik & Tin \\
Padaringan & Rice place \\
Batajak las & Stamping influence \\
\hline
\end{tabular}

The second category is verbs. There are 18 lexicons in This category that we found have shifted. The list of the 18 lexicons can be seen in the table below:

Table 8 The shift of Verbs in the Banjar language

\begin{tabular}{ll}
\hline Verb Vocabulary & Meaning \\
\hline Malunta & Looking for fish \\
Bagarit & Hunt \\
Madam & Homecoming \\
Maluntar & Fishing \\
Mamutung & Cutting rubber \\
Jihing & Smile \\
Sarak & Divorce \\
Mengoral & Looking for coral stones \\
Belabuh & To the market \\
Perai & Go home \\
Balalah & Walk \\
Bakudak & Photographed \\
Manggalau & Catching fish \\
Bererampaan & Create a playground \\
Balantik & Owe \\
Manungkih & Splitting wood \\
Ba'andah & Stopped \\
Disatil & Organize \\
\hline
\end{tabular}

The third category is an adjective. In this category, only five lexicons were found to have shifted. The list of lexicons in the adjective categories we found in the study is as follows: 
Table 9 The shift of adjectives in the Banjar language

\begin{tabular}{ll}
\hline Adjective Vocabulary & Meaning \\
\hline Dugal & Naughty \\
Halui & Small \\
Taguh & Brave \\
Disunduk & Locked/locked \\
Ambak & Quiet \\
\hline
\end{tabular}

The last lexicon category we examined was adverbs. In This category, there are only four lexicons that are our findings, as illustrated in the table below:

Table 10 The shift of Adverbs in the Banjar language

\begin{tabular}{ll}
\hline Adverb Vocabulary & Meaning \\
\hline Barendet & Rowdy \\
Bakula & Family \\
Badarau & Unison \\
Bajuju & Stammering \\
\hline
\end{tabular}

All lexicon in the four classes of words above experienced a shift due to changes in the natural and social conditions of Banjar society in general. Further details will be discussed in the next section.

There are several factors that cause regional language vocabulary in a region can become extinct, among which is due to natural disasters and also the loss of native speakers of regional languages (Chen, 2016; McMahon, 2002). For example, as explained in the previous section, Pengaron village in Banjar Regency is an area that is famous as a plantation area. However, over time, some vocabulary related to vegetables and fruits in the area has shifted. It is due to the increasingly easy human interaction that people from other regions can come and go to Pengaron which ultimately has an impact on the Banjar language in the area.

Here is an example of a lexicon of vegetable and fruit plants that have rarely been used in the village of Pengaron and the lexicon that replaces it:

Table 11 Examples of shifting lexicon of plants and vegetables in Banjar Language

\begin{tabular}{llll}
\hline Lexicon & Meaning & Replacement Lexicon & Information \\
\hline $\begin{array}{l}\text { Rambai } \\
\text { Tampurikat }\end{array}$ & $\begin{array}{l}\text { Fruit like langsat } \\
\text { Fruit like mangosteen but its } \\
\text { colour is yellow }\end{array}$ & $\begin{array}{l}\text { Kapul's rarely found. } \\
\text { Change the name }\end{array}$ \\
$\begin{array}{l}\text { Pampakin is like durian but its } \\
\text { colour is orange }\end{array}$ & Papakin & Change the name \\
\hline
\end{tabular}




\begin{tabular}{llll}
\hline Lexicon & Meaning & Replacement Lexicon & Information \\
\hline Lahung & $\begin{array}{l}\text { Fruit is like durian, but its } \\
\text { colour is red }\end{array}$ & Durian habang & Change the name \\
Sangkuang & $\begin{array}{l}\text { Her fruit is small like marbles } \\
\text { its sour and sweet taste }\end{array}$ & It's rarely found. \\
Kulidang & $\begin{array}{l}\text { Red flaky } \\
\text { The fruit is like hairless }\end{array}$ & - & Tiwadak habang \\
Kalumpe & Cambutan & $\begin{array}{l}\text { Change the name } \\
\text { It's rarely found. }\end{array}$ \\
Kalakai & Fern leaves & Pujuk gumbili & Change the name \\
Karayi & Cucumber & Sayur paku & Change the name \\
\hline
\end{tabular}

As seen in the table above, the Banjar language shift that occurred in Pengaron was influenced by the vocabulary of the Banjar language from other regions in South Kalimantan. It suggests that the interaction patterns of people living in South Kalimantan with different dialects can shift vocabulary in other dialects in the same language, Banjar.

Another example of a shift can be seen from the lexicon regarding animals that are no longer found or rarely spoken in the village of Pengaron as follows:

Table 12 Examples of shifting animal lexicon in Banjar Language

\begin{tabular}{llll}
\hline Lexicon & Meaning & Replacement Lexicon & Information \\
\hline Adupan & Dog & Kuyuk & Change the name \\
Anguy & Chameleon & - & It's rarely found. \\
Katikih & Large red ants & Salimbada & Change the name \\
Lalak & Frog & Kuduk & Change the name \\
Kijang & Deer & Binjangan & Change the name \\
Agas & Small mosquitoes & Rangit & Change the name \\
Anai-anai & White insects & Rayap & Change the name \\
Undur-undur & Group of insects & - & It's rarely found. \\
Tatangkut & Bee & Pinyangat & Change the name \\
Kakasiur & Dragonfly & Sisiur & Change the name \\
\hline
\end{tabular}

Like the lexicon associated with vegetables and fruits, the animal-related lexicon that shifts in the Pengaron area also only shifts locally. That is, the shift is influenced by the Banjar dialect, not from other languages. It shows that those who bring about change are fellow Speakers of Banjar. It's just that dialect differences cause a change of a few words.

In relation to social-environmental conditions, some of the Lexicon of Banjar language in Pengaron village that experienced a shift included the following: 
Table 13 Examples of shifts in the Lexicon of Banjar language related to social conditions

\begin{tabular}{lll}
\hline Lexicon & Replacement Lexicon & Meaning \\
\hline Madam & Mudik & Travel \\
Jamban & WC & Toilet \\
Bahual & Bekalahi & Hostile \\
Maluntar & Maunjun & Fishing \\
Bahanyut & Bakunyung & Swim \\
Berendet & Bajurut & Rowdy \\
Mamutung & Manurih & Cutting rubber \\
Dugal & Macal & Naughty \\
Baulanja & Batutukar & Buy \\
Rengge & Lunta & Fishnet \\
Halui & Halus & Small \\
Manyungkal & Menabuk & Dig \\
Indung & Uma & Mother \\
Jihing & Takurihing & Smile \\
Taguh & Harat & Brave \\
\hline
\end{tabular}

In addition, there is also a lexicon that is no longer used or rarely used because of natural changes. For example, the word " $b a$ ' $a h$ ", which means a sudden flood, is almost no longer understood by young Banjar speakers in the village of Pengaron. It happens because of changes in nature in the village that the river has not overflowed suddenly like in the past because of the arrangements that have been made on the river in the village.

Another lexicon that has rarely been heard or has undergone a shift in meaning is "rumbih". "Rumbih" means landslide. The lexicon is rarely used by the people of Pengaron village because the landslide event that usually accompanies severe flooding is no longer here. Therefore, the use of the lexicon has become unusual in the present.

Another lexicon that is still often heard in Banjar speakers in other areas but is rarely found in Pengaron is melunta. Melunta means fishing activities. The lexicon became unusually heard in Pengaron because the village's river water had been polluted due to the explosion of coal mine bombs around Pengaron. Because the river is polluted, people rarely look for fish in the river. As a result, the word melunta is rarely used even though the meaning may still be understood by speakers of Banjar language in Pengaron.

The next lexicon that has rarely been spoken is charcoal. Charcoal means unworked land or land that is left unchecked. It happens because of changes in people's livelihoods in Pengaron when compared to a few decades ago. Currently, the land that was once used for farming has become part of the mining land. As a result, the lexicon related to land, such as charcoal, is no longer used by the community. 
The next lexicon that has also been very rarely used by the community in Pengaron is "bagarit". "bagarit" means hunting. The vocabulary is rarely used because there is not much more fauna found in the village of Pengaron due to the conversion of forests in the area that has been used as coal mining land and mountain rocks.

The above explanation proves that changes that occur in the speaker's environment, both physically and socially, will directly impact the language used by the community (Milroy \& Milroy, 2008).

In comparison, the Banjar language shift also occurred in the Mandikapau area of Karang Intan District of Martapura City, which is still one district with Pengaron. The area has a long and wide river formed from the Riam Kanan River Dam and the Intan Coral Dam. People from Mandikapau village mostly have livelihoods such as raising animals, gardening fruits and vegetables and tapping rubber. So that the lexicons used show the natural conditions that exist there, for example, such as "motong" (tapping rubber), "bekaramba" (raising fish), "manyadot batu” (the work of sucking stones from the river), "mambuat batu” (transporting large stones into trucks then the stone is brought and sold).

As the time progress and nature change, there are many vocabularies that are no longer used or rarely used so that the vocabulary slowly disappears (Kenter et al., 2015; Meara, 2004). It happens because of natural changes such as the destruction of objects in the environment. One example is the "mengoral" lexicon. "Mengoral" means looking for coral stones. The word is no longer heard in the village of Mandikapau. It is due to the availability of coral stones in the village that can no longer be found as before. As a result, the community does not work as coral stone seekers anymore.

Examples of other vocabulary such as "halu" and "lasung" (nouns) have also been very rarely spoken. It used to be used to destroy coffee. "Halu” and "lasung" have rarely been heard even not used anymore because of the absence of people who make coffee by destroying their own coffee beans today. Furthermore, there are no more people who grow coffee plants in It Mandikapau village. Nowadays, everything is instant. There are already many instant coffees sold in kiosks so that people do not have to painstakingly smooth coffee beans first to drink coffee.

There are also terms that are lost or no longer used in the Banjar language by the people of Mandikapau village, such as "batajak las". The term was originally used by ancient people in the game of dominoes to determine a win or lose. Originally "batajak las" were only a term in the game of dominoes, then became a term used every day in ancient times. The term is borrowed to describe a phenomenon. If there is a person who sticks his influence in a group, then that person 
is being "batajak las". The term is no longer used in Mandikapau. Even many children do not know the lexicon.

The language a person uses is generally influenced by each person's socio-economic circumstances (Lacher, 2006; Schwab \& Lew-Williams, 2016; Wagner et al., 1993; Walsh, 2006, 2011). People from good economic circles will generally get used to using Indonesian. They are also very attentive to the development of their language. While people whose socio-economic circumstances are low do not pay much attention to language development, and in general, people whose socio-economic conditions are low will use the language of the region when communicating (Schwab \& Lew-Williams, 2016). It is what happened in Mandikapau. Here we can see a person's language from his economy. If they are from good economic circles, they usually tend to use Banjar language mixed with Indonesian, and if they are from low economic circles, they tend to only use Banjar language, which is somewhat old-fashioned or has rarely been used to communicate with people. Additionally, when someone starts to adapt to their environment, their marginal economy will change (Fill \& Mühlhäusler, 2001). Moreover, there is an assumption that Indonesian is cooler than the local language.

From the study, we can see that changes in the Banjar language have occurred and will definitely continue to occur. Changes can occur either because of the community of language users themselves or other factors related to the physical condition of nature. In general, the shift that occurs in Banjar languages in different regions that the language is used is due to the influence of other languages or Banjar languages from different dialects or sub-dialects. The shift in language can be clearly seen from the differences in usage and knowledge related to certain lexicons between older speakers and young ones. One day it is very likely that some lexicon in the Banjar language will be lost because it is shifted by another lexicon with the same meaning.

Examples of the lexicon in Banjar language that is rarely found in several different regions where the language is spoken are as follows:

Hambin: Courtyard

Almanak: Calendar

Atang: A place to cook

Balik: Cans

Suluh: Torch light

Menungkih: Splitting wood

Badarau: In unison

Menggalau: To catch fish

$B a$ 'andah: To stop by 
Padaringan: Rice holder

Perai: Home/finish

Lalungkang: window

Bakudak: To take picture

Sasudu: Spoon

Landau: Knee

Biuku: Turtoise

Bererampaan: To create a place to play

Both in the Banjar Hulu and Banjar Kuala areas, the lexicon above has begun to be rarely used, even some are no longer understood by speakers of Banjar (Arini, 2016). As an illustration, we will briefly explain what examples of shifts occur in the lexicon above.

"Lalungkan", which means that the window is rarely used in Speakers of Banjar in the Hulu area. Hence, based on the results of the interview, then it is only spoken by speakers who have aged. The word has been replaced by a window taken from the Indonesian language.

"Bakudak" was once commonly used as a verb that indicates photo activities. Nowadays it is rare for Banjar speakers, especially those who are young, to use the lexicon to show the meaning of taking pictures. The flow of information and technological developments make more Speakers of Banjar using lexicon absorption from Indonesian such as taking pictures or "bafoto" and also terms taken from foreign languages selfie if the "bakudak" activity refers to taking photos of yourself.

"Sasudu", which was once a lexicon that is commonly used to refer to one of the cutleries, has rarely been heard in the Banjar language. The lexicon shifted into a lexicon that is understood by all Indonesians, namely "sendok".

Ridges which are lexicons related to architecture in the Banjar language, have also begun to be rarely heard. Today the Banjar people are more familiar with the word "atap" than "bubungan" to refer to the same object that is one part of the house.

"Landau" used to be often spoken to refer to the knee. Currently, Banjar people often use the lexicon "lintuhut" or knee to replace the use of "landau".

"Biuku" as one of the animals that are often found in the area of South Kalimantan that has many rivers, is also rarely used. Most Banjar people now use the turtle lexicon to refer to the same animal as the "biuku".

The last lexicon that is an example in the study is "bererampaan". "bererampaan" is a lexicon that means making a place to play. The word is taken from the root of the word rampa, 
which means playground. "rampa" itself has something to do with nature. In the past, "rampa" refers to bamboo that is arranged and used as a place to play or a place to sit. Nowadays, it is rare for people to use the word. In areas with the livelihoods of the people, the word "bererangan" is replaced by "beleladangan", which has the same meaning. Once again, the shifting demonstrates the strong interconnectedness of language with the environment.

In conclusion, the shift in Banjar language does not only occur in the Area of Pengaron and Mandikapau in Banjar Regency. Broadly speaking, the shift in Banjar language occurs in different regions with different dialects and sub-dialects of Banjar. That is, the shift is inevitable given the dynamic human nature and the nature of language, which is also not static. The shift in the Banjar language that is happening today will continue. The question is, will the shift threaten the Banjar language and could lead to extinction? We think the shift in Banjar language, for now, will not cause the Banjar language to go extinct, considering that speakers of the language are still very much in number. Moreover, Banjar is a language that is not only spoken in South Kalimantan but also in other provinces such as East Kalimantan. In addition, the shift in Banjar language that occurred is not only caused by the influence of foreign languages or national languages but also due to the influence of the sub-dialect of Banjar itself.

\section{CONCLUSION}

From this study it can be concluded that the environment, both physical and social, has an impact on the shift that occurs in the Banjar language. Language shifts in Banjar language occur in a short period of time. Therefore, it is not uncommon to find a lexicon whose meaning is still understood by parents but is familiar to younger Banjar speakers. Language shifts are common in any language in the world. However, the rate of the shift must be considered in the framework of regional language participation.

\section{ACKNOWLEDGEMENT}

This research is funded by STKIP PGRI Banjarmasin. Hence, the researchers would like to thanks for all the support during the duration of the research.

\section{REFERENCES}

Arini, D. N. (2016). Politeness Distinction: Terms of Address Used by Banjerese Youth in Daily Life. Langkawi: Journal of The Association for Arabic and English, 2(2), 233-248. https://doi.org/10.31332/LKW.V2I2.465

Chen, S. (2016). Language and ecology: A content analysis of ecolinguistics as an emerging 
research field. https://doi.org/10.1016/j.amper.2016.06.002

Fill, A., \& Mühlhäusler, P. (Eds.). (2001). The Ecolinguistics Reader: Language, Ecology, and Environment

Continuum. https://linguisticstudentindonesia.files.wordpress.com/2019/11/alwin-fill-peter-muhlhausler-theecolinguistics-reader_language-ecology-and-environment-2001.pdf

Kenter, T., Wevers, M., Huijnen, P., \& De Rijke, M. (2015). Ad hoc monitoring of vocabulary shifts over time. International Conference on Information and Knowledge Management, Proceedings, 19-23-Oct-2015, 1191-1200. https://doi.org/10.1145/2806416.2806474

Lacher, H. (2006). Beyond Globalization. Capitalism, territoriality and the international relations of modernity. 224. https://doi.org/10.1017/CBO9781107415324.004

Lind $\varnothing$, A. V., \& Bundsgaard, J. (2000). Dialectical Ecolinguistics: Three Essays For The Symposium 30 Years of Language and Ecology in Graz December 2000. Odense : Research Group for Ecology, Language \& Ideology, Odense University. http://www.jcbang.dk/main/ecolinguistics/Dialecticalecolinguistics.pdf

Lubis, I. S. (2014). PergeseranBahasa dalam PermainanTradisional MasyarakatMandailing: Kajian Ekolingustik. Jurnal Telangkai, 8(2), 54-61.

McMahon, A. M. S. (2002). Understanding Language Change. Cambridge University Press. https://books.google.co.id/books?hl=en\&lr=\&id=8vqm1 zozD18C\&oi=fnd\&pg=PP13\&dq=langu age+change+due+to+natural+surroundings\&ots=JDahnC5156\&sig=Bxqy_GW4CqUVxMSF0C TItwUWcZA\&redir_esc $=\mathrm{y} \# \mathrm{v}=$ onepage $\& \mathrm{q}=$ language change due to natural surroundings $\& \mathrm{f}=$ false

Meara, P. (2004). Modelling Vocabulary Loss. Applied Linguistics, 25(2), 137-155. https://doi.org/10.1093/APPLIN/25.2.137

Milroy, J., \& Milroy, L. (2008). Linguistic change, social network and speaker innovation1. Journal of Linguistics, 21(2), 339-384. https://doi.org/10.1017/S0022226700010306

Mukhtar. (2013). Metode Penelitian Deskriptif Kualitatif. GP Press Group.

Schwab, J. F., \& Lew-Williams, C. (2016). Language learning, socioeconomic status, and childdirected speech. Wiley Interdisciplinary Reviews. Cognitive Science, 7(4), 264. https://doi.org/10.1002/WCS.1393

Sitanggang, G. F., Nurlela, Widayati, D. (2018). Leksikon - Leksikon bidang Kelautan Sibolga: Kajian Ekolinguistik. Jurnal Stindo Profesional, 4(4), 15-28. http://jurnalstipro.com/wpcontent/uploads/2019/01/2_green_fanny_sitanggang_jurnal_mei_2018_edisi_4.pdf

Wagner, G., Burkhauser, R., Behringer, F. (1993). The English Language Public Use File of the German Socio-Economic Panel. The Journal of Human Resources, 28(2), 429-433. https://www.jstor.org/stable/146211

Walsh, J. (2006). Language and socio-economic development: Towards a theoretical framework. Language Problems and Language Planning, 30(2), 127-148. https://doi.org/10.1075/LPLP.30.2.03WAL

Walsh, J. (2011). Contests and Contexts: The Irish Language and Ireland's Socio-economic 
Development. Peter Lang AG. https://books.google.co.id/books?hl=en\&lr=\&id=cxiZTNctxcC\&oi=fnd \&pg=PR9\&dq=language + and + socio-

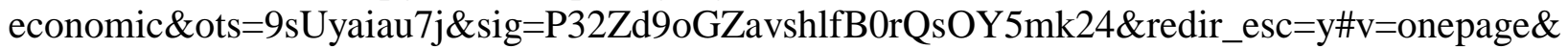
$\mathrm{q}=$ language and socio-economic $\& \mathrm{f}=$ false

Zainuddin, H. (2008, March 3). Pengaruh Melayu dan Dayak dalam Bahasa Banjar. Antara News. https://www.antaranews.com/berita/95257/pengaruh-melayu-dan-dayak-dalam-bahasa-banjar 